DOI https://doi.org/10.18551/rjoas.2018-02.10

\title{
THE INFLUENCE OF ECONOMIC VALUE ADDED AND MARKET VALUE ADDED ON CORPORATE VALUE
}

\author{
Taslim Fadli Ali \\ Faculty of Economics, Khairun University, Ternate, Indonesia \\ E-mail: fadlitaslim207@gmil.com
}

\begin{abstract}
This research aims to determine the influence of economic value added and market value added on corporate value of manufacturing companies on sector consumer goods industry listed in Indonesia Stock Exchanges of 2011-2014. The sample of this research was 10 manufacturing companies on sector consumer goods industry listed in Indonesia Stock Exchanges. The method used was purposive sampling technique. This research used confirmatory factor analysis to form a combined proxy of corporate value comprised price earning ratio, price to book value and Tobin's $Q$.
\end{abstract}

\section{KEY WORDS}

Market, corporate value, technology, economy.

Technology has been growing fast so that the business competence among the companies is tighter, so is the smaller or bigger manufacturing companies. This encourages a manager to be more careful to make a decision. Because investor will truly pay attention the performance of company's financial where s/he invests. For that matter, company's financial performance is the basis of significant assessment for investor, creditor, management, banking or government to assess the stability of company's financial management. Company's performance assessment is generally assessed with a financial ratio which actually is a technique or a method to analyze financial statement. Good company's performance is reflected by its financial statement consisted of; revenue, gross profit, and net income that result in a positive value at every end of the administration period. This information can be a company's procedure driver and is used by management to formulate a policy in the effort of being in accordance with the continuously changing condition.

EVA is a modern company's financial performance assessment method popularized and has been granted patents by Stern Stewart management Service's Consultant Company of Stern Stewart \& Co New York America. Company's performance assessment is truly needed by a company to maximize the invested funds by the external party to the company's internal party. EVA Approach is where EVA tries to measure the added value resulted by a company through subtracting the cost of capital rising because of investment that has been conducted. EVA sets a good benchmark that company has given a value added to the shareholder. For that matter, finance manager focusing on EVA will help to ensure that they operate in a consistent way to maximize shareholder value Brighma \& Houston (2011, as cited in Zulfia, 2013). EVA's present value expected is MVA which is company's debt and capital market value from total capital used to support added value. In addition to EVA, MVA is also a measurement used to assess the success in maximizing shareholder's wealth by allocating the proper sources. MVA is also able to measure how much the company's wealth resulted by its investor or NVA which states the size of welfare achieved.

The objective of this research is to determine and analyze the influence of EVA on corporate value and to analyze the influence of MVA on corporate value.

\section{LITERATURE REVIEW}

Signalling Theory. Signalling theory was initially developed by Ross in 1979. This theory was the result of information asymmetrical in which a condition where the manager 
has more information on operation and company's prospect in the future Tambunan (2008, as cited in Mursalim, 2009). Signalling theory accentuated the importance of information issued by the company towards foreign company's investment decision. Information is an important element for investor and other business people since it actually presents past, present and future description, notes or illustration for company's continuity. Complete, relevant, accurate, and meet deadline information is truly needed by an investor in the capital market as an analysis tool to make an investment decision.

One of the information types issued by a company which can be a good signal for foreign parties, especially investor is an annual report. Information disclosed in annual report can be an accounting information i.e. information related to the financial statement and nonaccounting information, that is information which is not related to the financial statement. The annual report should contain relevant information and reveals information considered important to be known by those using the report both external and internal party. All investors need information to evaluate company's relative risk so that able to conduct portfolio diversification and investment combination with risk preference wanted. If a company wanted to get an investor, it had to conduct financial statement disclosure openly and in a transparent way.

Agency Theory. Barleg and Mean (1933, as cited in Muhammad Umar Mai, 2010) states about ownership separating and company's control so that share ownership distribution was important for a company. When a company is no longer managed by the principals but trusted to someone else, so the problem arises was the potential of conflict in the relationship between principals and agent which was commonly called agency problem.

Jensen (1986, as cited in Muhammad Umar Mai, 2010) explains that the conflict of manager interest and shareholder interest occurred with shareholders and manager assumption in which each of them wanted to get a higher return on investment projects but different interests on risk. This conflict can be found at a company with bigger free cash flow since the manager will make an investment for the excess cash obtained from internal fund sources to optimize its personal gains by not making cash dividend payment to the shareholder. Agency problem exists since there was information asymmetrical between shareholder and manager, which was when one of the parties has information that another party has not.

At a modern company whose ownership was spread and the management was separated, capital needs were not only supplied by principals or shareholder but were possible to use funds from other sources that are debtholders, in this matter agency problem can be wider. In an implicit way, there are three forms of agency relationship i.e. relationship between principals and management, a relationship between creditor and management, and a relationship between government and management. Hence the principals or the company owner can be the shareholder, creditor, or government. Agency theory identified the potential of conflict of interest between various concerned parties within the company. Those conflicts were caused by a goal difference of each party based on the position and its interest towards the company. In order to solve this problem, it needed a mechanism control and interest balance between manager and stakeholders.

Company's Financial Performance. According to the Minister of Finance Decree No. 740/KMK.00/1989 concerning the Improvement of Efficiency and Productivity of StateOwned Enterprise, "Financial Performance was an achievement resulted by a company in a particular period reflecting the level of company health. Company's Financial Performance was one of the bases of assessment on financial conditions that could be conducted based on the analysis of financial ratio." While according to Mursalim (2009) current performance measurement was a combination between finance and non-finance information which would also produce a financial report (e.g. profit and cost of share increases) and non-finance performance (for example customer satisfaction). Company's financial performance could be measured by analyzing and evaluating company's financial statements. Along with the current development and information needs regarding company's performance, it appears a value-based new measurement tool. Those measurement methods were among other EVA and MVA. 
Economic Value Added (EVA). EVA was initially popularized by Stern Steward Management Service's consultant company from the United States in the 1980s. EVA was after-tax operating income subtracted by the total cost of capital. The total cost of capital was the rate of cost of equity multiplied by invested total capital Utama (as cited in Resmi, 2003). Positive EVA expressed the resulted rate of return was higher than the rate of capital return asked by an investor, which meant a company had maximized the corporate value. Conversely, negative EVA meant the corporate value decreases so that the rate of return gained was lower than the rate of return expected by the investor which meant the company did not succeed to create value for the capital owner (Resmi, 2003).

Market Value Added (MVA). The major target of almost all companies was maximizing shareholder's wealth. It would be maximized by minimizing the difference between market value of company's share and total equity capital which has been given by shareholder. The difference was called Market Added Value Brigham (as cited in Zaky \& Ary, 2002). MVA was a difference between company's market value (including equity and money) and the whole capital invested in a company. Market value was corporate value. It meant the total market value of all capital claims towards a company by a capital market in particular date. MVA increased if only the capital invested a larger return than the cost of equity. The larger the MVA, the better the result. Negative MVA meant the value from the investment run by management was less than the capital given to a company by the capital market. It meant the wealth has been destroyed (Younf, 2001:27).

Corporate Value. Financial management actually aimed to maximize the corporate value. Corporate value could be seen from market value or company's book value from its equity. Because of the balance sheet, the equity demonstrates total company's capital. In addition, the capital market can be a measurement of corporate value. Company assessment did not only refer to par-value. It was caused by a company condition which experiences many changes every time significantly. Before getting a crisis, the corporate value and parvalue are high, but after getting a crisis the company condition decreased while the par-value was as common. A company was said having good value if the company performance was also good. Corporate value can be reflected from the previous price. If the share value was high, the corporate value was possible to be good too.

\section{METHODS OF RESEARCH}

This research was undertaken at manufacturing companies on sector consumer goods industry listed in Indonesia Stock Exchanges. The duration of the research was 2 months that was from November 3rd until December 29th, 2015.

The population of this research was 39 manufacturing companies on sector consumer goods industry listed in Indonesia Stock Exchanges with the observation period of 2011 until 2014. The method used to get the sample was purposive sampling method; the sample was selected based on the sample characteristic relevance with determined selection criteria.

Table 1 - Sample Collection Criteria

\begin{tabular}{|l|c|c|}
\hline \multicolumn{1}{|c|}{ Criteria } & $\begin{array}{c}\text { Total } \\
\text { Company }\end{array}$ & $\begin{array}{c}\text { Total Observation } \\
\text { Data }\end{array}$ \\
\hline $\begin{array}{l}\text { Total manufacturing companies on sector consumer goods industry listed in } \\
\text { Indonesia Stock Exchanges 2011-2014 }\end{array}$ & 39 & - \\
\hline $\begin{array}{l}\text { Sample reduction criterion 1: Manufacturing companies on sector consumer } \\
\text { goods industry having no listing age more than 5 years in ISE }\end{array}$ & - & - \\
\hline $\begin{array}{l}\text { Sample reduction criterion 2: A company which did not publish the 2011-2014 } \\
\text { financial report completely and continuously }\end{array}$ & 23 & - \\
\hline $\begin{array}{l}\text { Sample reduction criterion 3: A company suffering from assets and equity } \\
\text { loss }\end{array}$ & 3 & - \\
\hline Total sample used in the research (13 $\times 4)$ & 13 & 52 \\
\hline
\end{tabular}

Source: processed secondary data. 
Type of data used to conduct this research was quantitative data, while the data source used was secondary data obtained from the financial report which can be accessed in electronic media like www.IDX.com and www.sahamoke.com. The data needed to conduct this research was financial statement summary data of a company which has gone public.

The researcher used a documentation method collected from secondary data search. Documentation was conducted by collecting documentary data sources like a summary of company's financial statements.

Data analysis techniques used was quantitative analysis. Quantitative analysis was a measurement used in a research which can be benefited with a particular total unit or stated by numbers. This analysis comprised data processing, data organizing and finding the result. The data testing provided to this research was using regression model and analysis tool used was factor analysis and multiple regression.

Dependent Variable. Dependent variable used to conduct this research was Corporate Value variable. Corporate Value used to conduct this research was:

- PER can be calculated using Formulation Tandelilin (2007, as cited in Kurniawan, 2009):

$$
\mathrm{PER}=\frac{\text { Price of per sheet share }}{\text { Gains of per sheet share }}
$$

- Corporate Value's PBV was calculated by dividing current capital close price with recent quarter book value per share. It was also known as "price-equity ratio". Measurement scale used was formulated as follow (Wulandari, 2009):

$$
\mathrm{PBV}=\frac{\text { Price of per sheet stock market }}{\text { Value of per sheet stock market }}
$$

- Tobin's $Q$, this ratio was a valuable concept since indicating an estimation of current financial market concerning return result value of every dollar of incremental investment. Tobin's $Q$ was calculated by comparing the ratio of company's capital market value with company's equity book value. It can be calculated as follow:

$$
\mathrm{Q}=\frac{(E M V+D)}{(E B V+D)}
$$

Where: $\mathrm{Q}=$ corporate value; $\mathrm{EMV}=$ equity market value; $\mathrm{EBV}=$ book value from total active; $\mathrm{D}=$ book value from total debt.

Independent Variable. EVA was after-tax operating income subtracted by the total cost of capital. The total cost of capital was the rate of cost of equity multiplied by invested total capital Utama (as cited in Resmi, 2003). If EVA was positive so that the resulted rate of return was higher than the rate of capital return asked by the investor, which meant that a company had maximized the corporate value. Proxies representing EVA value were NOPAT, Capital Charges, WACC, and Invested Capital.

NOPAT was profits gained from company operation after being subtracted by income tax. NOPAT could be formulated as follows: Amin Widjaya Tunggal (as cited in Rina Ulfiani, 2006).

Net Operating Profit After Tax + rate 
Capital charges were EVA' essential aspect. Since Capital Charges was also cash flow needed to replace the investor for the business risk of the capital invested. Capital Charges could be formulated as follow: Amin Widjaya Tinggal (as cited in Rina Ulfiani, 2006).

Capital Charges $=$ WACC $\mathrm{x}$ Invested Capital

WACC was the cost of equity and cost of debt which each of them was multiplied with the percentage of equity and debt in a company model Lisa Linawati Utomo (as cited in Rina Ulfiani, 200:58). The way to calculate WACC was using formula as follow: Yevi Dewiyanti (as cited in Rina Ulfiani, 2006).

$W A C C=\{D \times$ rd $(1-$ Tax $)\}+\{E \times$ re $\}$

Invested Capital was the whole total of company loan excludes short-term loans without rate. For example accounts payable, funds that still should be paid, tax payable added by equity. Invested Capital could be calculated using the formula below: Yevi (as cited in Rina Ulfiani, 2006).

Invested Capital $=$ Total Debt and Equity - short-term debt without interest

Djawahir Kusnan (2007) states that market value added reflected shareholder expectation towards the company in creating wealth in the future. MVA was the difference between market value of equity and book value of equity. Market Value Added (MVA) could be calculated using such below formula by Agus Sartono (as cited in Yevi Dewiyanti in Rina Ulfiani, 2006):

MVA $=($ Stock Price - Book Value $) \times$ Outstanding Share

Positive MVA showed that management had been able to increase shareholder's wealth while negative MVA caused the reduced capital value of shareholder, if MVA was 0 , so the company was not able to increase wealth for the shareholder. Hence maximizing MVA value should be the company's principal goal to increase shareholder's wealth (Zaky, 2002).

\section{RESULTS AND DISCUSSION}

The object of this research was manufacturing companies on sector consumer goods industry listed in Indonesia Stock Exchanges of 2011-2014. According to the sampling selection as the determined criteria, so it was chosen 13 companies fulfilling the criteria of the sample.

Data Analysis Result. Confirmatory Factor Analysis was used to obtain factor score which was a general index value of single proxy creating Corporate Value variable. Each ratio value used as Corporate Value Proxy was calculated every year for a sample company and then used as data input in the analysis factor process.

Confirmatory Factor Analysis in Table 1 above indicated that not all correlation value was above 0.30 , however; some of the correlation value was above 0.30 so that factor analysis can be continued. Correlation presented was bivariate Pearson correlation coefficient by $0.375,0.187$, and 0.235 .

According to the Kaiser-Meyer-Olkin-Measure of sampling adequacy which was above 0.50 , that is 0.583 ; the value was categorized as "more than enough" of suitable to conduct 
factor analysis. In addition to KMO test, it was also conducted Anti Image Correlation (MSA) test to know if variables were partially proper to be analyzed and were not issued in the test. According to table 1 above, it was shown that three variables which would be analyzed indicating higher MSA value than 0.50, i.e. $0.570,0.562$ and 0.668 .

Table 1 - Factor analysis result of Corporate Value Proxy

\begin{tabular}{|c|c|c|c|c|}
\hline \multicolumn{5}{|c|}{ A. Bivariate Person Correlation Coeficient } \\
\hline \multicolumn{2}{|c|}{ Single Proxy of Corporate Value } & PER & PBV & Q \\
\hline \multirow{3}{*}{ Correlation } & PER & 1.000 & .375 & .187 \\
\hline & PBV & .375 & 1.000 & .235 \\
\hline & Q & .187 & .235 & 1.000 \\
\hline \multicolumn{5}{|c|}{ B. KMO and Bartlet'ts Test } \\
\hline \multicolumn{4}{|c|}{ Kaiser-Meyer-Olkin Measure of Sampling Adequacy } & .583 \\
\hline \multirow{3}{*}{$\begin{array}{l}\text { Bartlett's Test of } \\
\text { Sphericity }\end{array}$} & \multicolumn{3}{|c|}{ Approx. Chi-Square } & 10.830 \\
\hline & \multicolumn{3}{|c|}{ Df } & 3 \\
\hline & \multicolumn{3}{|c|}{ Sig } & .013 \\
\hline \multicolumn{5}{|c|}{ C. Measure of sampling adequacy (MSA) } \\
\hline \multirow{3}{*}{$\begin{array}{l}\text { Anti-image } \\
\text { Correlation }\end{array}$} & PER & $.570 a$ & & \\
\hline & PBV & & $.562 a$ & \\
\hline & Q & & & $.668 \mathrm{a}$ \\
\hline
\end{tabular}

Source: processed secondary data.

Table 2 - Multiple Regression Result

EVA and MVA regression analysis on combined proxy of Corporate Value (PER, PBV and Tobin's Q)

\begin{tabular}{|c|c|c|c|c|c|c|}
\hline \multirow{2}{*}{\multicolumn{2}{|c|}{ Model }} & \multicolumn{2}{|c|}{ Unstandardized Coefficients } & \multirow{2}{*}{$\begin{array}{l}\text { Standardized Coefficients } \\
\text { Beta }\end{array}$} & \multirow{2}{*}{ t-count } & \multirow{2}{*}{ Sig. } \\
\hline & & $\mathrm{B}$ & Std. Error & & & \\
\hline \multirow{3}{*}{1} & (Constant) & $-0,027$ & 0,166 & & $-0,164$ & 0,87 \\
\hline & EVA & 0.007 & 0 & $-0,168$ & $-1,165$ & 0,25 \\
\hline & MVA & $-0,015$ & 0 & 0,13 & 0,901 & 0,372 \\
\hline $\mathrm{R}$ & \multicolumn{6}{|l|}{0,188} \\
\hline $\mathrm{R}^{2}$ & \multicolumn{6}{|l|}{$0-, 004$} \\
\hline F count & \multicolumn{6}{|l|}{0,897} \\
\hline Sig $\mathrm{F}$ & 0.415 & \multicolumn{5}{|c|}{ N 52} \\
\hline T table & \multirow{2}{*}{\multicolumn{6}{|c|}{$\begin{array}{l}1.677 \\
\text { ant), EVA MVA }\end{array}$}} \\
\hline \multirow{2}{*}{\multicolumn{7}{|c|}{$\begin{array}{l}\text { a. Predictors: (Constant), EVA, MVA } \\
\text { b. Dependent Variable: NP }\end{array}$}} \\
\hline & & & & & & \\
\hline \multicolumn{7}{|c|}{ EVA and MVA regression Analysis on PER } \\
\hline \multirow{2}{*}{\multicolumn{2}{|c|}{ Model }} & \multicolumn{2}{|c|}{ Unstandardized Coefficients } & Standardized Coefficients & \multirow[b]{2}{*}{ t-count } & \multirow{2}{*}{ Sig. } \\
\hline & & $\mathrm{B}$ & Std. Error & Beta & & \\
\hline \multirow{3}{*}{1} & (Constant) & 2380.317 & 547,574 & & 4,347 & 0 \\
\hline & EVA & $-0,001$ & 0,001 & $-0,13$ & $-0,894$ & 0,376 \\
\hline & MVA & 0.012 & 0 & 0,044 & 0,302 & 0,764 \\
\hline $\mathrm{R}$ & \multicolumn{6}{|l|}{0,128} \\
\hline $\mathrm{R}^{2}$ & \multicolumn{6}{|l|}{$-0,024$} \\
\hline F count & \multicolumn{6}{|l|}{0.406} \\
\hline $0.415 \quad N 52$ & \multicolumn{6}{|l|}{$0,669 \mathrm{~N} 52$} \\
\hline T table & \multicolumn{6}{|l|}{1,677} \\
\hline \multirow{2}{*}{\multicolumn{7}{|c|}{$\begin{array}{l}\text { a. Predictors: (Constant), EVA, MVA } \\
\text { b. Dependent Variable: PER }\end{array}$}} \\
\hline & & & & & & \\
\hline \multicolumn{7}{|c|}{ EVA and MVA regression analysis on PBV } \\
\hline \multirow{2}{*}{\multicolumn{2}{|c|}{ Model }} & \multicolumn{2}{|c|}{ Unstandardized Coefficients } & Standardized Coefficients & \multirow{2}{*}{$t$-count } & \\
\hline & & $\mathrm{B}$ & Std. Error & Beta & & Sig. \\
\hline & (Constant) & 271,668 & 40,561 & & 6,698 & 0 \\
\hline 1 & EVA & $-0,005$ & 0 & $-0,18$ & $-1,279$ & 0,207 \\
\hline & MVA & 0.012 & 0 & 0.256 & 1,817 & 0,075 \\
\hline $\mathrm{R}$ & 0,278 & & & & & \\
\hline $\mathrm{R}^{2}$ & 0,04 & & & & & \\
\hline F count & 2,057 & & & & & \\
\hline $0.415 \quad N 52$ & 0.139 & & & & & \\
\hline T table & 1,677 & & & & & \\
\hline
\end{tabular}




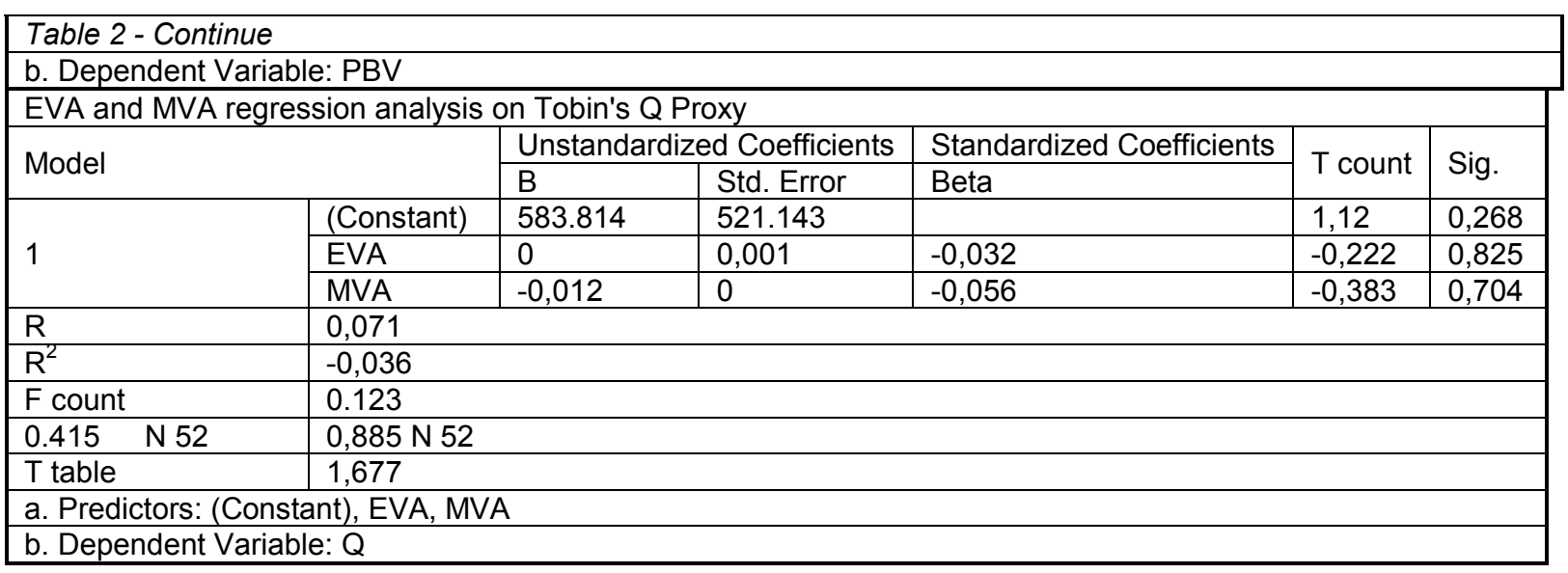

Table 1 above concluded that those three corporate value's proxies met the qualification so that factor score value obtained was then used as the value representing Corporate Value's single proxy. This factor score was a general factor of Corporate Value in which factor score value obtained will be used more in regression analysis.

In order to achieve the research objective and to know if the independent variable had an influence on the dependent variable or not, so multiple regression analysis should be conducted. Multiple regression results can be seen in table 2.

According to the regression estimation result as shown in Table 2 above, so multiple regression equation was as follow:

- Multiple Regression analysis of corporate value's equation:

$$
N P=-0.027+0.007 E V A-0.015 M V A+e
$$

The equation above was explained as follow:

Multiple regression equations indicated constant value by -0.27 and had a negative value. That value means if independent variable i.e. EVA and MVA were 0 (zero) or constant, so the corporate value was -0.027 . $\beta 1$ value by 0.007 indicated that if EVA variable increases $1 \%$, so the corporate value would increase by 0.007 . $\beta 2$ value by -0.015 means if MVA decreases by $1 \%$, the corporate value increases by 0.015 .

- Multiple regression of PER proxy equation

$$
\text { PER }=2380.317-0.001 E V A+0.012 \mathrm{MVA}+\mathrm{e}
$$

Multiple regression equations indicated constant value by 2380.317 and had a positive value. That value means if independent variable i.e. EVA and MVA were 0 (zero) or constant, so PER value was 2380.317 . $\beta 1$ value by -0.001 meant if EVA variable decreased by $1 \%$, so PER increases by 0.001 . $\beta 2$ value by 0.012 means if MVA variable increases by $1 \%$, so PER will increase by 0.012 .

- Multiple Regression analysis of PBV proxy equation:

$$
\mathrm{PBV}=271.668-0.005 E V A+0.012 \mathrm{MVA}+\mathrm{e}
$$

The equation above was explained as follow:

Multiple regression equations indicated constant value by 271.668 and had a positive value. That value means if independent variable both EVA and MVA is 0 (zero) or constant, so PBV value is 271.668 . $\beta 1$ value by -0.005 meant if EVA variable decreased by $1 \%$, so PBV increased by 0.005 . $\beta 2$ value by 0.012 means if MVA variable increases by $1 \%$, so PBV increases by 0.012 .

- Multiple Regression Analysis of proxy $Q$ equation.

$$
\mathrm{Q}=583.814-0.0 \mathrm{EVA}-0.012 \mathrm{MVA}+\mathrm{e}
$$


Multiple regression equations showed constant value by 583.814 and had a positive influence. That value meant if independent variable both EVA and MVA were 0 (zero) or constant, so $Q$ value was 583.814 . $\beta 1$ value by -0.0 meant if EVA variable decreased by $1 \%$, so $Q$ value increased by -0.0 . $\beta 2$ value by -0.012 meant if MVA variable decreased by $1 \%$, so there would be an increase by 0.012 .

\section{DISCUSSION OF RESULTS}

The Influence of Economic Value Added (EVA) on Corporate Value. Positive EVA value meant a company was able to produce effective and efficient financial performance which meant the rate of return resulted did not exceed the cost of equity for the rate of return expected by the investor. Positive EVA also indicated that company was able to create maximum corporate value for capital owner assisted with the increase of cost of equity which will be able to increase rate of return, hence according to the research result, EVA did not have a significant influence on corporate value (PER, PBV and Tobin's $Q$ ) which meant even though corporate's EVA value increased, it did not guarantee the corporate value would increase too, and vice versa.

This finding was not consistent with the research conducted by Melinda Septiyanti et al. (2013) revealing that Economic Value Added (EVA) had a significant influence on Corporate Value (Tobin's Q). This inconsistency showed that EVA analysis was not always used as a basis of decision making by an investor to buy or sell company's share and was also not used by management to make a decision of dividend share. EVA was not always used as a basis of performance since EVA calculation was not simple compared to performance size which was commonly used like financial ratio.

Signaling theory was an effect of financial report disclosure understood by the reader, especially actors of the stock exchange, information about what happened at manufacturing companies on sector consumer goods industry today showed investor characteristic which will assess it as bad signal, so the investor will not buy a share from the company.

The Influence of Market Value Added (MVA) on Corporate Value. Positive MVA showed that company's market value is higher than company's book value. This should make investor interested in making an investment in a company. The number of investors who were interested should be able to increase the number of demands of share so that being able to increase the share price. The increase of share price will bring a positive influence on the return reflected from the increase of corporate value. However, according to the analysis result, it was known that Market Value Added (MVA) did not have a significant influence on Corporate Value, while MVA had a not significant influence on PBV. This showed that even though company's MVA value increases, it does not guarantee the corporate value (PER, PBV and Tobin's Q) increases too, and vice versa. This research was not consistent with the study carried out by Melinda Septiyanti et al. (2003) finding that Market Value Added (MVA) had a significant influence on Corporate Value. This inconsistency has shown that MVA analysis was not always used as a basis of decision making by management, as Puji Astuti (2006) said that MVA was only used as a method of alternative financial performance reflected by MVA showing weak effect on financial performance.

This research result also told us that interest conflict between manager and shareholder has been attacking manufacturing companies on sector consumer goods industry, with assumptions that each shareholder and manager wanted to get a high return to the investment projects but different interest to the risk. Pawlina and Renneboog (2005, as cited in Muhammad Umar Mai, 2010) also state that this conflict attacked a company with bigger free cash flow since the manager will make an investment for excess cash obtained from internal funds source to maximize his/her personal gains by not making cash dividend payment to the shareholder. If this information is published and investor considered it as a decision to make an investment so that the investor will not since every investor aimed to get a dividend in the future. 


\section{CONCLUSION AND SUGGESTIONS}

Economic Value Added (EVA) has a negative and not significant influence on corporate value (PER, PBV and Tobin's Q). Market Value Added (MVA) has no influence on Corporate Value, PER and Tobin's Q proxy, but MVA has a positive and not significant influence on PBV proxy. Negative EVA shows that a company less succeeds in creating value added to shareholder since EVA shows a residual profit after all cost of capital, while MVA shows the difference between market value equity and book value of equity.

It is better for further study to add other independent variables which can influence Corporate Value like Leverage, Systematic Risk and etc. which can influence Corporate Value. In addition, a further study can use much more companies as the sample, such as all manufacturing companies listed in Indonesia Stock Exchanges. Moreover, it also can use a selection of year of longer observation period since the longer the observation period the more the company grows.

\section{REFERENCES}

1. Djawahir, Kusnan M. 2007, S W A 100 peringkat EVA dan MVA terbaik 2007: para pencetak Kekayaan di pasar modal. Majalah SWA, No.26/2007.

2. Kurniawan, Theresia Yunianti. 2009. Pengaruh Economic Value Added dan Return On Asset terhadap Nilai Perusahaan. Unpublished Thesis, Accounting Department, Universitas Pembangunan Veteran.

3. Septiyani, M., Tandika, D., Azib. pengaruh Economic Value Added (EVA) dan Market Value Added (MVA) terhadap Nilai Perusahaan dengan menggunakan metode tobin's q (studi kasus pada Perusahaan dalam indeks LQ45 periode tahun 2010-2013). Unpublished Thesis, Faculty of Economics and Business, Universitas Diponegoro.

4. Mai, M.U. 2010. Dampak Kebijakan Dividen terhadap Nilai Perusahaan dalam kajian Perilaku Oportunistik Manajerial dan Struktur Corporate Governance (Studi Empiris pada Perusahaan Manufaktur Go Public di Pasar Modal Indonesia). Unpublished Dissertation, Faculty of Economics, Universitas Sebelas Maret.

5. Mursalim. 2009. Economic Value Added (EVA) dan Market Value Added (MVA) dampaknya terhadap Nilai Perusahaan. Jurnal keuangan dan Perbankan, 13(3): 498 505.

6. Resmi, Siti. 2003. Economic Value Added (EVA) sebagai pengukur Kinerja Perusahaan: sebuah kenyataan. Majalah Ekonomi, Year XIII, No.3.

7. Ulfiani, R. 2006. Pengaruh EVA dan Rasio Profitabilitas terhadap MVA. Unpublished Thesis, Faculty of Economics, Universitas Udayana.

8. Young, S. D \& S. E. O'Byrne. 2001. EVA dan Manajemen Berdasarkan Nilai: panduan praktis untuk implementasi. Jakarta: Salemba Empat.

9. Zaky \& Legowo, A. 2002. Asosiasi antara EVA (Economic Value Added), MVA (Market Value Added) dan Rasio Profitabilitas Terhadap Harga Saham. Tema, 3(2): 98-102.

10. Sari, Z.E. 2013. Pengaruh Profitabilitas, Leverage, Economic Value Added dan Risiko Sistematis Terhadap Nilai Perusahaan (studi empiris pada perusahaan kategori LQ45 yang terdaftar di BEI. Unpublished Thesis, Faculty of Economics, UIN Syarif Hidayatullah. 